\title{
A new species of the millipede genus Hyleoglomeris Verhoeff, 1910, from Tajikistan, Central Asia (Diplopoda: Glomerida: Glomeridae)
}

\author{
Новый виА диплопод рода Hyleoglomeris Verhoeff, 1910, \\ из Таджикистана (Џентральная Азия) \\ (Diplopoda: Glomerida: Glomeridae)
}

\author{
S.I. Golovatch \\ С.И. Головач
}

Институт проблем экологии и эволюции РАН, Ленинский проспект, 33, Москва 119071, Россия.

Institute for Problems of Ecology and Evolution, Russian Academy of Sciences, Leninsky prospekt 33, Moscow 119071, Russia.

KEY WORDS: Diplopoda, Hyleoglomeris, new species, Tajikistan.

КЛЮЧЕВЫЕ СЛОВА: Diplopoda, Hyleoglomeris, новый вид, Таджикистан.

ABSTRACT. A new species of the very large, basically warm temperate to tropical Eurasian genus Hyleoglomeris is described from Tajikistan: H. bohaci sp.n. This is only the second congener to be reported from Central Asia, differing from all members of the awchasica-group it belongs to by an indistinct colour pattern against a light yellowish brown dorsal coloration, from the geographically closest H. kirgisica Golovatch, 1976, from Kyrgyzstan, mostly in the less numerous striae on tergum 2, and the presence of a minute, thin, flagelloid filament on a cup-shaped top of each telopod syncoxital horn.

РЕЗЮМЕ. Из Таджикистана описан новый вид весьма большого, в основном тёплоумеренного до тропического, евразиатского рода Hyleoglomeris: H. bohaci sp.n. Это лишь второй вид в составе рода, отмеченный в Центральной Азии. Он отличается от всех членов группы видов awchasica, куда он относится, неясным рисунком на светлом желтоватобуром дорсальном фоне, а от географически ближайшего вида H. kirgisica Golovatch, 1976, из Кыргызстана, главным образом, и меньшим числом бороздок на тергите 2, и наличием очень мелкого, тонкого, жгутиковидного филамента на чашеобразном конце каждого рога синкоксита телопод.

\section{Introduction}

The genus Hyleoglomeris Verhoeff, 1910, is long known to dominate the Oriental fauna of the millipede order Glomerida, at the moment counting nearly 100 species ranging from Serbia and Greece in the west, through Anatolia, the Caucasus, Central Asia and the Himalayas to China, Korea, Japan and Taiwan in the east, and from Indochina to the Philippines and Sulawesi Island, Indonesia, in the southeast [Golovatch, 2013].
Only a single species of Hyleoglomeris has hitherto been described from Central Asia: H. kirgisica Golovatch, 1976, from the western Tian Shan Mountains of Kyrgyzstan [Golovatch, 1976; Read, Golovatch, 1994]. Golovatch et al. [2006] assigned it, together with the Anatolian and Caucasian congeners, to the awchasicagroup, based on the presence of a vivid colour pattern and a thin filament on top of each telopod syncoxital horn in most of the group's constituent species. In addition, in contrast to the Balkan and Greek members, none of the awchasica-group species is truly troglobitic.

Eventually, Hyleoglomeris has long been reported from Tajikistan, referred to as an apparently new species still to be described [Golovatch et al., 2006]. The present note provides its formal description, as it seems unreasonable to expect more glomerid material from Central Asia to become available for study in the near future.

Taxonomic part

Hyleoglomeris bohaci Golovatch, sp.n.

Figs $1-7$.

HOLOTYPE OT (ZMUM 22572 ), Tajikistan, Ghissar Mt. Range, Varzob Canyon, 1600 m a.s.1., Platanus orientalis litter, 26.IV.1983, leg. J. Boháč

PARATYPES: 3 우 (ZMUM $\rho 2573$ ), same data, together with holotype.

NAME. Honours Jaroslav Boháč, the collector.

DIAGNOSIS. This new species differs clearly from all members of the awchasica-group it belongs to by a rather uniform yellowish brown coloration devoid of a distinct pattern. It is easily distinguished from the geographically closest H. kirgisica Golovatch, 1976, from Kyrgyzstan, also by less numerous striae on tergum 2 (6 versus 9), the presence of a distinctly emarginated central lobe of the telopod syncoxite, and of a thin flagelloid filament on top of each of its horns.

DESCRIPTION. Length of holotype ca $6.5 \mathrm{~mm}$, width (maximum on tergum 2) ca $2.8 \mathrm{~mm}$; length of paratypes ca 


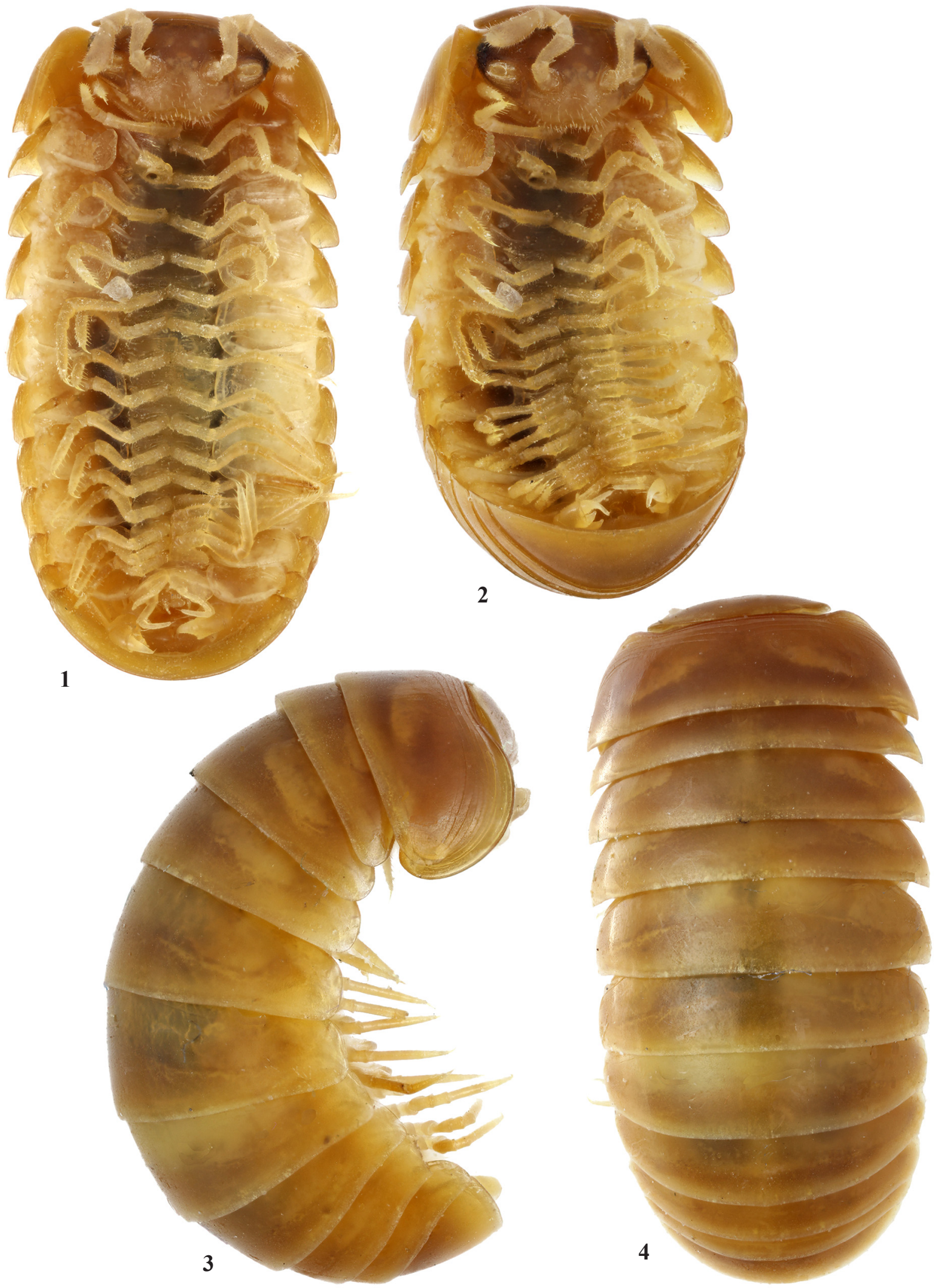

Figs 1-4. Habitus of Hyleoglomeris bohaci sp.n., O' holotype, ventral, subventral, lateral and dorsal views, respectively. Pictures by K. Makarov, taken not to scale.

Рис. 1-4. Общий вид Hyleoglomeris bohaci sp.n., голотип О7, соответственно снизу, почти снизу, сбоку и сверху. Фотографии К. Макарова, без масштаба. 


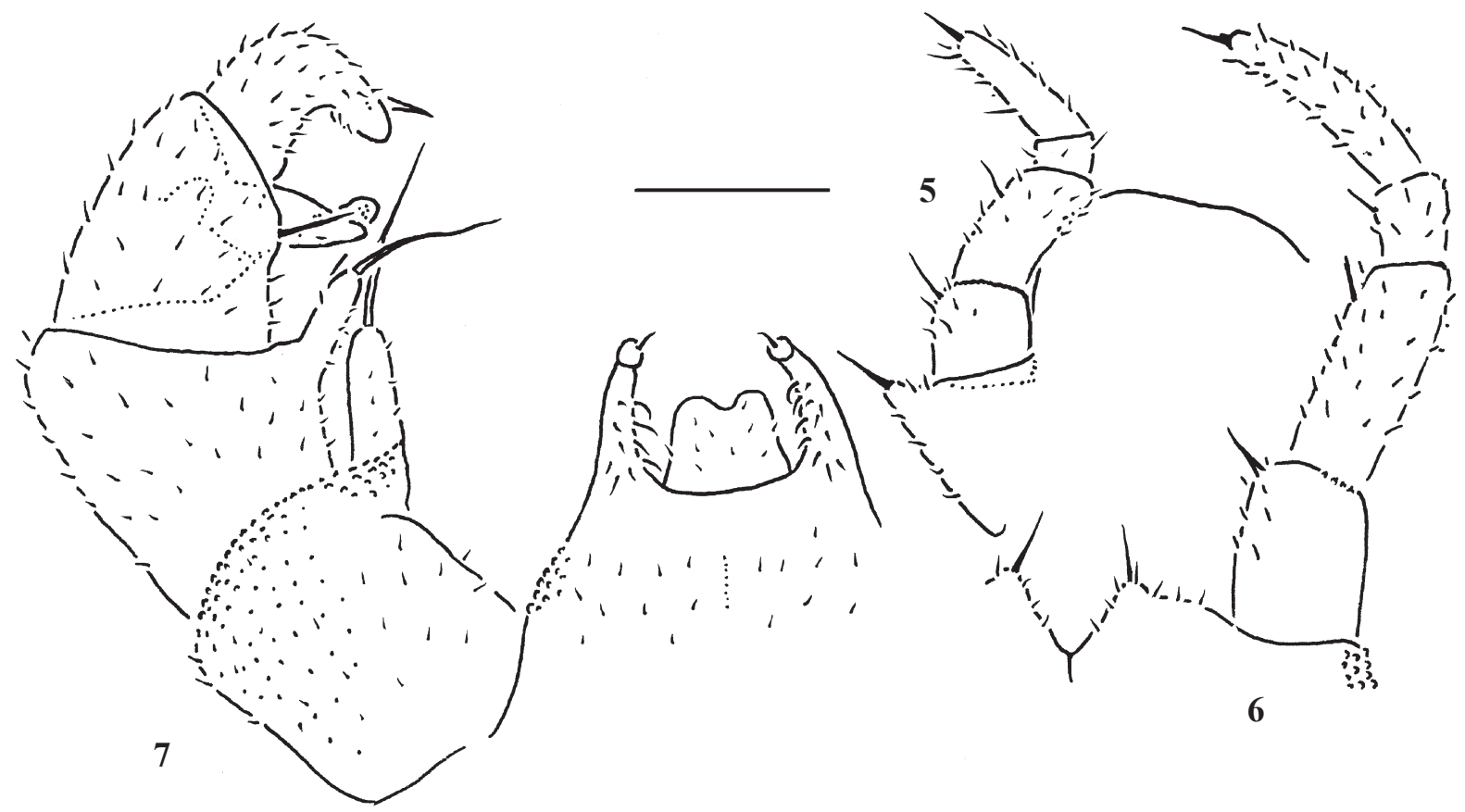

Figs 5-7. Hyleoglomeris bohaci sp.n., $\mathrm{O}^{7}$ holotype. 5 - leg 17, anterior view; 6 - leg 18, anterior view; 7 - leg 19 (= telopod), anterior view. Scale bar: $0.2 \mathrm{~mm}$.

Рис. 5-7. Hyleoglomeris bohaci sp.n., голотип О’, 5 - нога 17, спереди; 6 - нога 18, спереди; 7 - нога 19 (= телопод), спереди. Масштаб: 0,2 мм.

6.0-8.0 mm, width on tergum 2 ca $2.8-3.0 \mathrm{~mm}$. Body rather uniformly light yellowish brown, only ocelli dark brown to brown. Dorsal pattern vague, poorly traceable (Figs 1-4): collum with a lighter, marbled yellow-brownish, central spot only slightly separated by brown bands along lighter anterior and posterior margins, more broadly separated by brown, subtriangular spots from both lighter lateral ends; postcollum terga with a thin light axial stripe dividing oblong-oval, somewhat skewed, transverse, marbled yellow-brownish, paramedian spots lying in anterior halves of terga and separated from lighter caudal margins by narrow brown bands growing somewhat broader laterad and anteriad until lighter and broader lateral margins (Figs 3,4); last tergum (= pygidium) brown anteriorly, lighter brown-yellowish posteriorly along a broad, light, caudal margin (Figs 2,3). Head considerably infuscate (brown) above antennal sockets. Antennae, Tömösváry’s organs, legs and venter lighter, yellowish.

Ocelli 6+1, convex, completely translucent. Tömösváry's organ transverse-oval, ca 1.4 times wider than long. Antennomere 6 rather long, ca 2.2-2.3 times as long as high. Collum with two transverse striae. Tergum 2 with a narrow hyposchism not reaching behind caudal tergal margin; 6-7 superficial transverse striae, only one starting below schism, one level with, all others above schism while three (never last one from below) crossing the dorsum. Pygidium regularly rounded at caudal margin.

$0^{T}$ leg 17 (Fig. 5) with a high, rather regularly rounded, outer coxal lobe; telopodite 4-segmented, tarsus with one strong apical spine.

$\sigma^{7}$ leg 18 (Fig. 6) with a subtriangular syncoxital notch; telopodite 4-segmented, tarsus with one apical spine.

$\sigma^{7}$ legs 19, or telopods (Fig. 7), with a high, deeply emarginate, central syncoxital lobe flanked by two setose horns, each latter clearly higher than a distinctly emarginated central lobe and crowned by a small cup-shaped tip carrying a minute, elongate, acuminate, membranous filament. Prefemur micropapillate laterally. Caudomedial femoral process simple, prominent, directed distomedially at ca $120^{\circ}$ to femur, mostly strongly chitinized, only apically with a small membranous sac. Caudomedial process of tibia evident, sacshaped, membranous, with a distinct, small, rounded tubercle on caudal face at base. Tarsus rather strongly curved, narrowly rounded apically.

ACKNOWLEDGEMENTS. I am most grateful to Jaroslav Boháč (Prague, Czech Republic) for having rendered me his material for study. Kirill Makarov (Moscow, Russia) skillfully took all pictures.

\section{References}

Golovatch S.I. 1976. [New or little-known species of Glomeridae (Diplopoda, Oniscomorpha)] // Zoologicheskii zhurnal. Vol.55. No.6. P.931-935 [in Russian, with English summary].

Golovatch S.I. 2013. Three new species of the millipede genus Hyleoglomeris Verhoeff, 1910 from the Aegean region of Greece (Diplopoda, Glomerida, Glomeridae) // Biodiversity Data Journal. Vol.1. P.1-13. e1000. doi: 10.3897/BDJ.1.e1000.

Golovatch S.I., Geoffroy J.-J., Mauriès J.-P. 2006. Review of the millipede genus Hyleoglomeris Verhoeff, 1910 (Diplopoda, Glomerida, Glomeridae), with descriptions of new species from caves in Southeast Asia // Zoosystema. Vol.28. No.4. P.887915.

Read H., Golovatch S.I. 1994. A review of the Central Asian millipede fauna // Bulletin of the British Myriapod Group. Vol.10. P.59-70. 